\title{
ON THE KARELIDES IN THE TOHMAJÄRVI AREA, EASTERN FINLAND
}

\author{
OSMo NyKäNEN
}

\begin{abstract}
Nykänen, Osmo 1971: On the Karelides in the Tohmajärvi area, eastern Finland. Bull. Geol. Soc. Finland 43, 93-108.

The evolution of the Karelides in the Tohmajärvi area is discussed.

The Karelidic schists (metasediments) are devided into two stratigraphic groups, the Jatulian and the Kalevian, which likewise represent two different sedimentation facies. The Jatulian metasediments are so-called evolutionary sediments, deposited under relatively peaceful conditions in marginal parts of the continental block, partly in a shallow transgressive sea. These continentalepicontinental sediments were originally weathering gravel, quartz sands, bituminous and calcareous sediments, which were metamorphosed into metaconglomerates, quartzites, black schists and dolomites. The Kalevian metasediments are revolutionary sediments, chemically weakly weathered and mixed with sand and clay, which deposited rather rapidly into fold basins formed during orogenic movements. They are so-called flysch (Wegmann 1928, 1929) sediments and form the phyllite - mica schist group.

Besides the normal metasediments, the Jatulian group comprises pyroclastic sediments and hypabyssic and metabasaltic effusives which erupted during the initial stages of the Svecofenno-Karelidic orogeny. In the southern part of the schist area there are smaller Late-Karelidic granite intrusions which together with the orogenic movements caused regional metamorphism under conditions of amphibolite facies where staurolite and andalusite porphyroblasts crystallized in mica schists and phyllites.
\end{abstract}

Osmo Nykänen, Geological Survey of Finland, Otaniemi, Finland.

\section{CONTENTS}

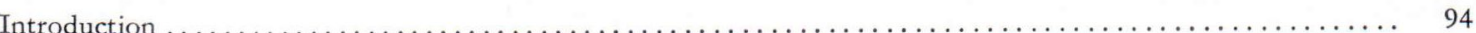

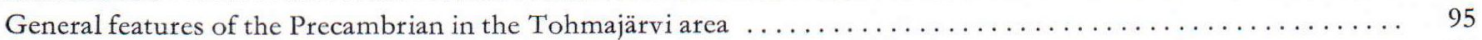

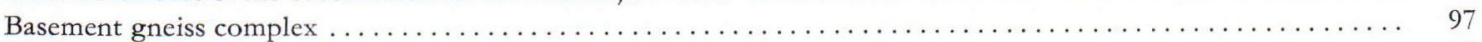

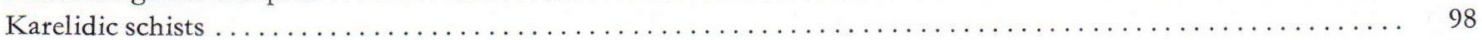

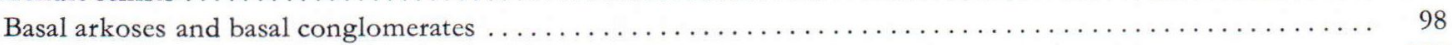

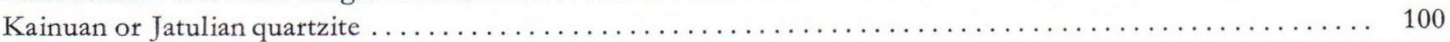

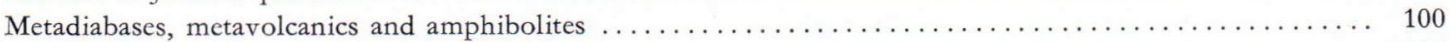

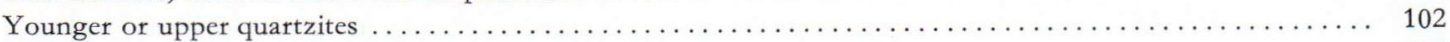

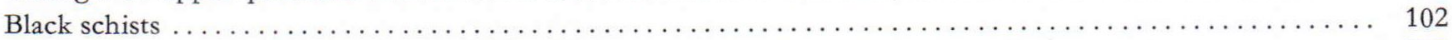

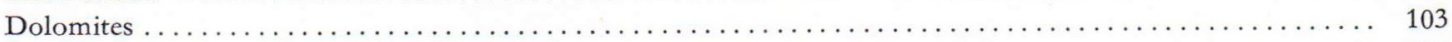

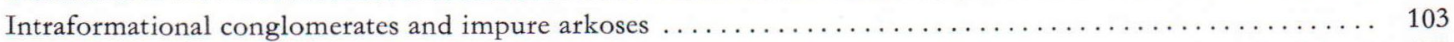

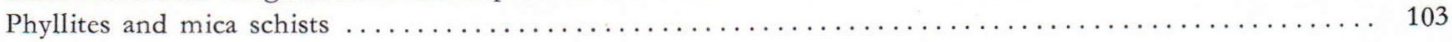




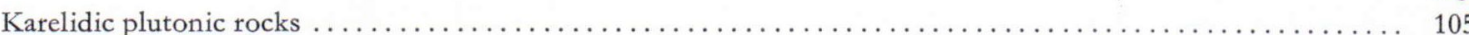

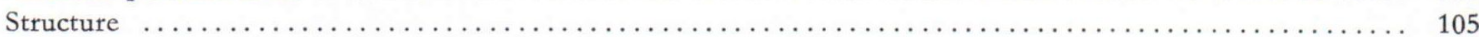

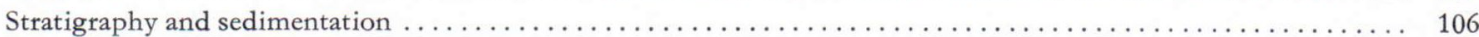

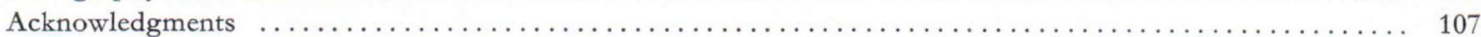

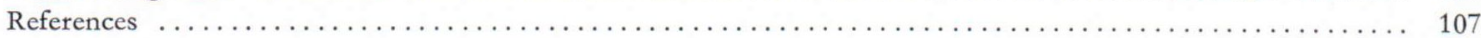

\section{Introduction}

The area investigated comprises $40 \times 40$ square kilometres in North Karelia, East Finland (Fig. 1). The research material was obtained in connection with the geological mapping of the Geological Survey during the years 1962-68.

The western part of the area belongs to the Karelides and the eastern part to the so-called

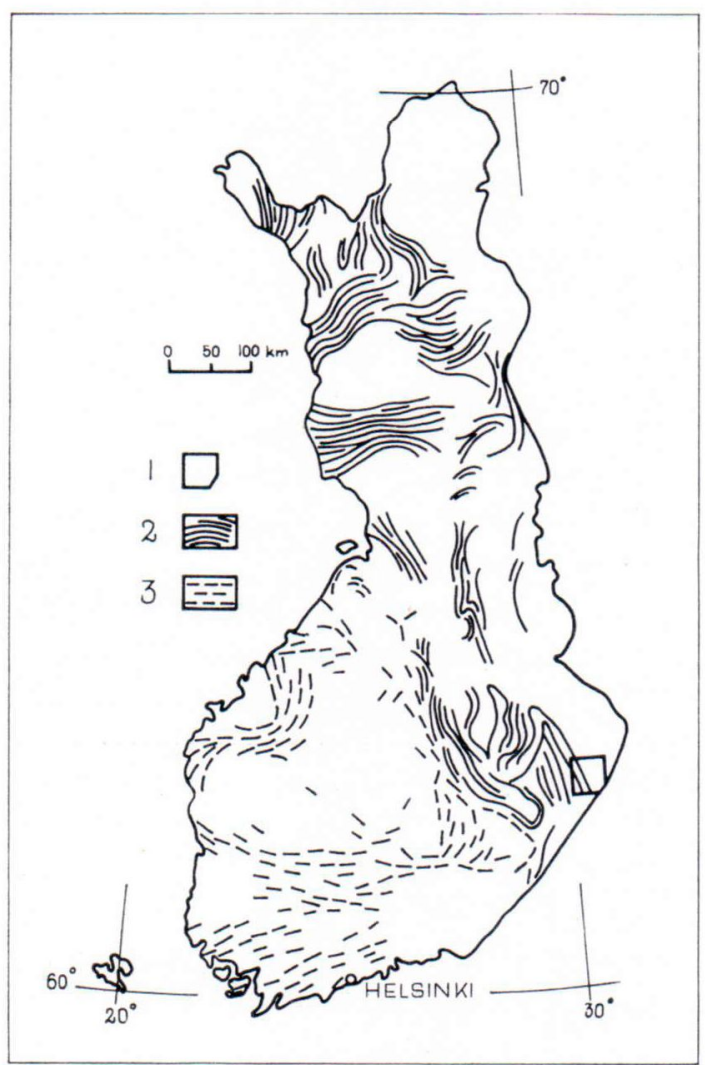

Fig. 1. Index map. 1. The square next to the border is the research area. 2. Karelidic schist belt. 3 . Svecofennidic schist belt.
Pre-Karelidic basement gneiss complex or the granite gneiss area. The Karelides are the folded mountain range which originated during the Precambrian era and extends from Lake Ladoga to Lapland. Their deeply eroded root zones or the Karelidic schist belts remain. The Karelian sediments deposited on the basement gneiss complex and folded during the Karelidic orogeny.

As early as 1874 Wiik, in connection with his studies on the Pre-Cambrian area of Eastern Finland, came to the conclusion that the gneiss formation (= basement gneiss complex) was the oldest. In his opinion, the fine-grained schists (mica and chlorite schists) lie upon this. The youngest ones were the clastic sediments (quartzites).

Tigerstedt (1892) assumed that the conglomerates, quartzites, phyllites and limestones of Karelia formed a sequence deposited discordantly on the sea floor on the granite gneiss basement. The granite-gneiss basement was later called the basement gneiss complex (Simonen 1960, Eskola 1963).

Sederholm $(1893,1897)$ connected the schist formations of Karelia with the Huronian system of North America. He named the quartzites Jatulian and the phyllite-mica schist formation Ladogian.

Sederholm regarded the contact relationships between granites and schists as a decisive factor in his stratigraphic classification. He held the Ladogian schists to be older than the Jatulian quartizites because the Ladogian schists were penetrated by granites and were more strongly metamorphosed than the Jatulian quartzites.

Later, however, phyllites and mica schists, not penetrated by granites, were found in the 
Karelidic schist belt. Frosterus and Ramsay (1902) called these schists the Kalevian section and considered them younger than the Ladogian schists which were penetrated by granites. They regarded the Kalevian schists older than the Jatulian.

Nevertheless, Frosterus and Wilkman (1920) found out during geological mapping that there are granites which also penetrated the Kalevian schists. Thus the border between the Kalevian and Ladogian schists remained vague.

Eskola (1925) comprehended the Ladogian, Kalevian and Jatulian schists of Eastern Finland as a unit, the so-called Karelian formations, whose folding and metamorphism all took place within one single orogeny, the Karelidic orogeny. He named the Jatulian polymictic basal conglomerates Sariolian conglomerates.

Wegmann $(1928,1929)$ pointed out the Alpine type structures of the Karelides. According to the Alpine pattern the Jatulian corresponded to the foreland sediments, the Kalevian to the flysch sediments and the Ladogian to the geosyncline sediments. The old granite gneiss area was the resistance area against which the Karelian schists were pushed from the west.

Väyrynen (1933, 1954) divided the metasediments of the Karelian formations into different sedimentary facies:

Kalevian phyllites and mica schists

Jatulian $\left\{\begin{array}{l}\text { (black schists) and dolomites } \\ \text { Kainuan quartzites } \\ \text { Sariolan arkoses and conglomerates }\end{array}\right.$

The Jatulian - according to Väyrynen - was older than the Kalevian. Likewise Väyrynen (1933, 1954) and Hackman (1933) regarded the boundary between the Kalevian and Ladogian schists as vague. Väyrynen (1954) pointed out that the Ladogian staurolite-bearing phyllite is directly joined to the Kalevian formation in the north, in the Tohmajärvi area.
Until the 1950's the Karelides were regarded as younger than the Svecofennides in the west. Simonen (1960) and T. Mikkola (1961) proposed that the Svecofennides and Karelides are probably different sedimentary facies of the same orogeny. This proposition was suppoted by age determinations (Kouvo 1958) showing that the orogenic granites of the Svecofennides and Karelides were of the same age. T. Mikkola considered the Jatulian as a shelf facies and the Kalevian as a miogeosyncline facies in the Svecofenno-Karelidic (or Fennidic, as T. Mikkola says in 1961) orogenic cycle.

The radiometric age determinations by $O$. Kouvo give the main phase of the pre-Karelian orogeny to be around $2600-2800 \mathrm{~m}$.y. The main phase of the Svecofenno-Karelidic orogenic movements lies at $1900 \mathrm{~m}$.y. according to the ages measured so far.

\section{General features of the precambrian in the Tohmajärvi area}

The bedrock of the Tohmajärvi (Fig. 2) area is divided geologically into two complexes with a great discordance inbetween:

1. The old basement gneiss complex or the granite gneiss complex in the eastern part of the area. 2. The Karelidic schists or Karelides in the western part of the area.

The basement gneiss complex - the ancient Jatulian continent - extends far into the Soviet side. The basement gneisses of the Tohmajärvi area are mainly strongly metamorphosed silicic plutonic rocks, orthogneisses (gneissose granites). They are cataclastic, partly striped, similar to veined gneisses or strongly migmatitized granodiorites and quartz diorites and granites. The paragneisses occur only sporadically. In the basement gneiss area there are abundant metadiabase dikes younger than the rocks of the basement gneiss complex and which were formed during the initial phase of the SvecofennoKarelidic orogeny. 

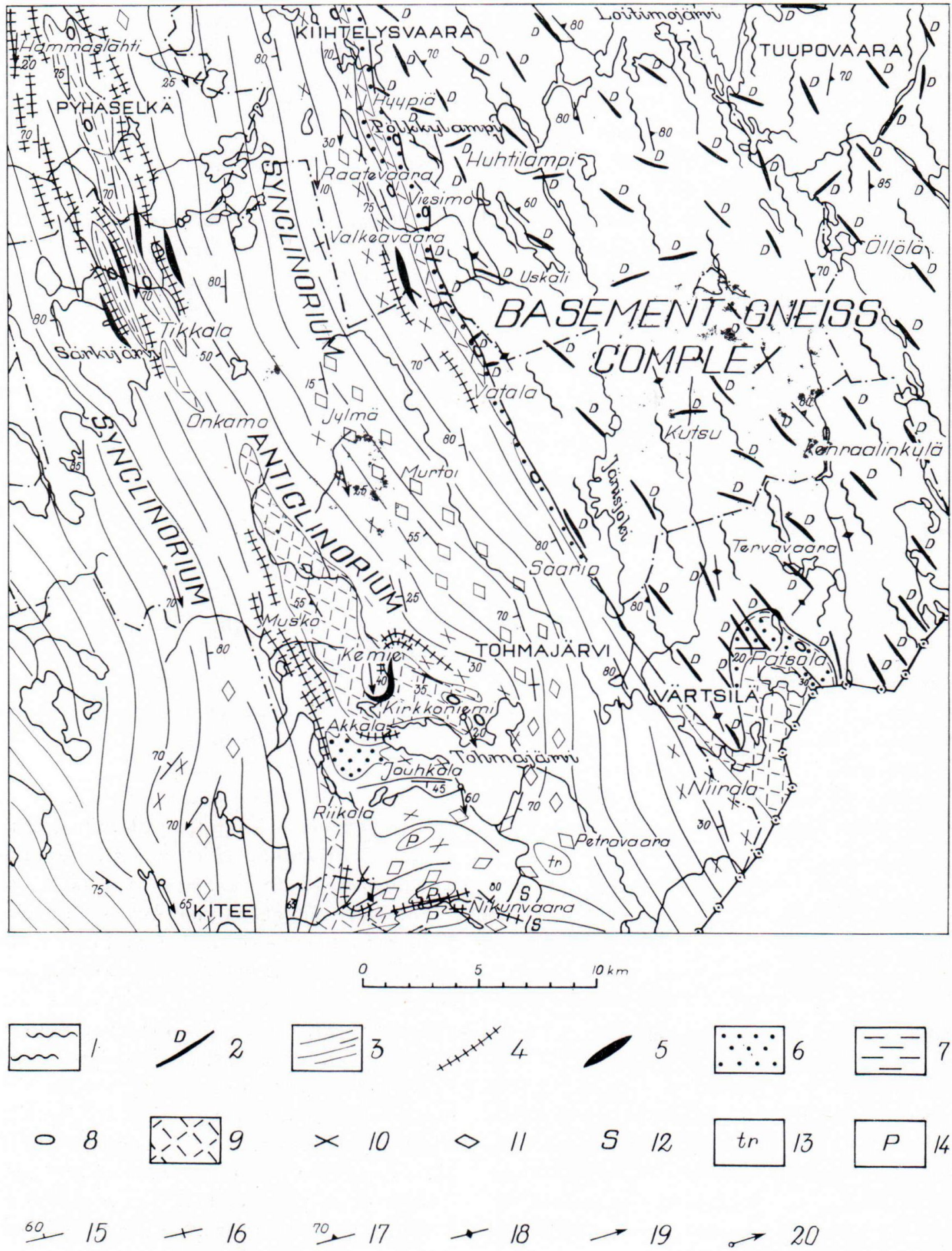

Fig. 2. Geological map of the Tohmajärvi area. Legend. 1. Gneissose granite, partly veined gneiss and migmatite.

2. Metadiabase as dikes in the basement gneiss area. 3. Phyllite and mica schist. 4. Black schist. 5. Dolomite. 6. Quartzite. 7. Meta-arkose. 8. Conglomerate. 9. Metavolcanics and amphibolite. 10. Staurolite. 11. Andalusite. 12. Sillimanite. 13. Trondhjemite. 14. Pegmatitic granite. 15. Bedding. 16. Vertical bedding. 17. Foliation. 18. Vertical foliation. 19. Lineation. 20. Fold axis. 
The Karelidic schist zones have a NNW trend. In the Tohmajärvi area the Kareleides divid structurally into two wide syncline basins with an anticlinal ridge between them. The basin of Höytiäinen lies in the east and that of Pyhäselkä in the west (Väyrynen 1954). The Kalevian phyllites predominate in the synclinal basins. The anticlinal ridge extends from Hammaslahti through Tikkala and Onkamo to the village of Tohmajärvi. Peculiar to the anticlinal ridge are the rocks of the metavolcanics-amphibolite complex, the black schists and dolomites of the marine Jatulian as well as the intraformational conglomerates and impure arkoses.

At the eastern border of the Karelidic schists against the basement gneiss complex there is a $1 \mathrm{~km}$ broad belt of Jatulian metasediments where the dip of bedding slopes steeply westward. As the Karelian metasediments of Tohmajärvi are autochtonic as regards the basement gneiss area, in other words, they lie approximately on their depositing base, the sequence of bedding can be followed westwards from the border of the basement gneiss complex. The lowermost are the Sariolian basal conglomerates and arkoses. Above these is the distinct zone of the Kainuan or Jatulian orthoquartzite, and topmost are the metavolcanics, younger quartzites, black schists, dolomites and phyllites.

Staurolite and andalusite porphyroblasts originated in the phyllites and mica schists of the Tohmajärvi area during metamorphism. It can be seen from the geological map that the porphyroblastic schists divide into two main zones: the staurolite-mica schist zone and the andalusite-mica schist zone. The staurolite-mica schist zone lies close to the anticlinal zone, partly near to the border of the basement gneiss area with the andalusite-mica schist zone in the Höytiäinen basin.

Small intrusions of late- Karelidic granites occur on the southern border of the area. They belong to the wide granite massif of Kitee, south of the investigation area.

\section{Basement gneiss complex}

Cataclastic gneissose granite (Fig. 3), quartz diorite or granodiorite as to its composition, is the most common rock of the basement gneiss area. It is grey, mostly coarse and generally orientated. Striped and migmatitic varieties are common. The main constituents are plagioclase $\left(A n_{15-25}\right)$ and quartz; the amounts of biotite, hornblende and potash feldspar vary. Mafic minerals form 10-30 per cent. Gneissose granite comprises pale oligoclase granitic and pegmatitic portions and quartz veins.

In the basement gneiss area, there is a zone of cataclastic granite which is a few kms. broad. The granite penetrates and migmatitizes other rocks of the basement gneiss complex. The granite is reddish grey, mostly coarse-grained, in places indistinctly porphyritic and most often showing parallel texture. The main minerals are potash feldspar, plagioclase $\left(\mathrm{An}_{10-20}\right)$ and quartz with 5-10\% mafic minerals-mostly mica.

The amphibole and chlorite schists represent the pre-Karelian schist group, whose deposition floor has not yet been found. The schists occur

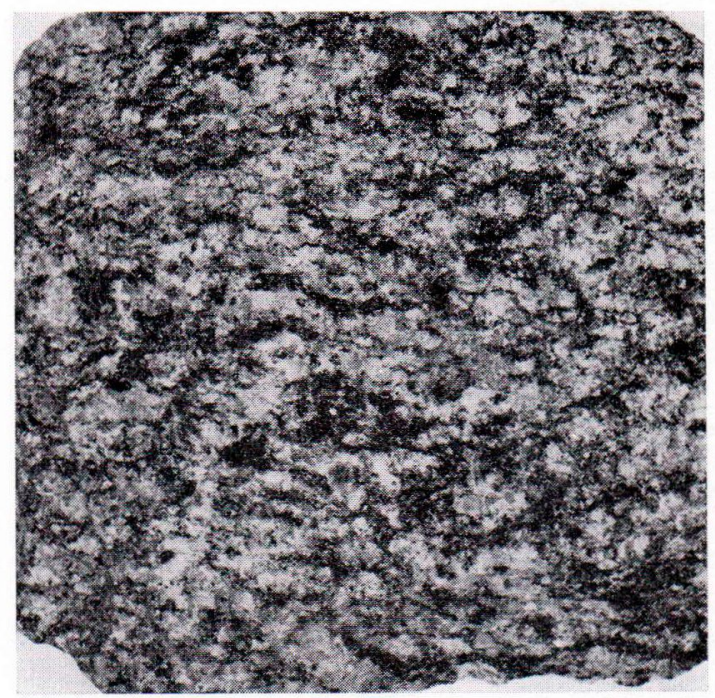

Fig. 3. Cataclastic gneissose granite (quartz diorite). $4 / 5$ natural size. Kihtelysvaara, Sammalvaara. Photo Erkki Halme. 
as narrow zones or rows of inclusions. They may be relics of pre-Karelian volcanic rocks, lava rocks and tuffites.

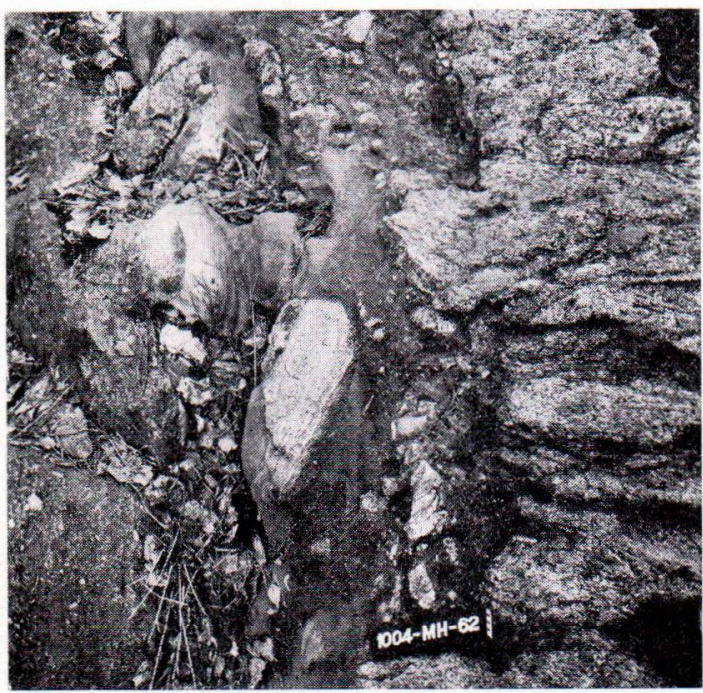

Fig. 4. Discordance between basal conglomerate and gneissose granite. Kiihtelysvaara, Pölkkylampi. Photo Maunu Härme.

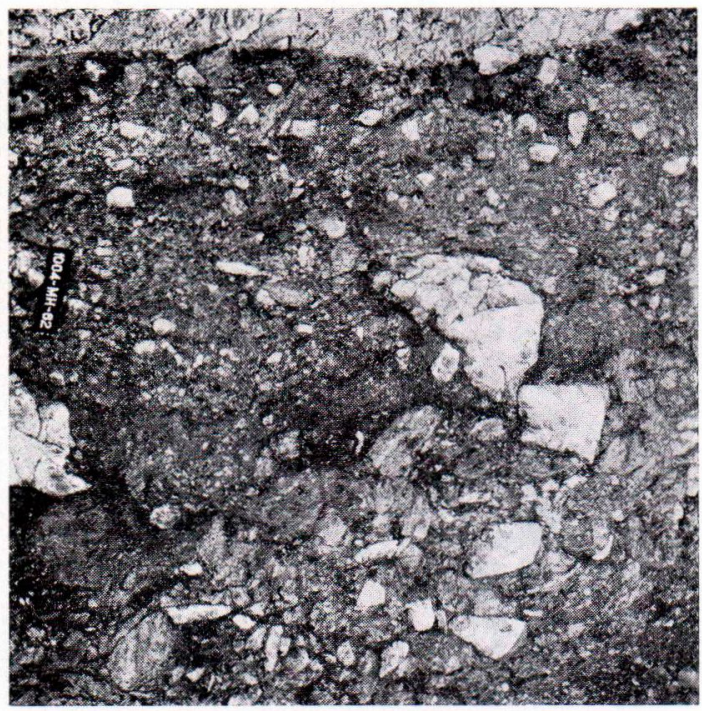

Fig. 5. Conglomerate with angular pebbles from the lower part of the formation. Kiihtelysvaara, Pölkkylampi. Photo Maunu Härme.
The metadiabases of the basement gneiss area form a dike system where the dikes seem to locate in the fracture and shear zones. A 20 $100 \mathrm{~m}$ wide dike is quite common. The metadiabases are most often medium-grained, partly coarse dark green gabbrolike or metaophitic hypabyssal rocks. In composition, they correspond to tholeiitic basalt. The principal minerals are hornblende and plagioclase $\left(\mathrm{An}_{10-40}\right)$, of which there are 60 and $20-25 \%$ respectively. A low content of quartz is common. In places the metadiabase dikes show signs of magmatic differentiation, in which case the most basic zone is at the border and the silica content increases towards the center of the dike where a narrow leucodiabase zone composed of 40 per cent albite $\left(A n_{5-10}\right), 20-30$ per cent quartz and about 40 per cent dark minerals (chlorite and hornblende) also occurs. The metadiabases of the basement gneiss area intruded during the initial phase of the Karelidic orogeny and are the products of the same magmatic activity as the metavolcanics of the Karelidic schist area. Feeding channels through which the magma erupted to the surface can be seen in places in the Jatulian quartzite.

\section{Karelidic schists}

\section{Basal arkoses and basal conglomerates}

In the Karelidic schists of Tohmajärvi the undermost layer is a poorly sorted basal arkose which is associated with polymictic basal conglomerates. Below this Sariolian meta-arkoseconglomerate zone there is a bed of saprolitic schist which is several tens of metres thick and which corresponds to the ancient in situ weathered surface of the basement gneiss complex from which particularly calcium and sodium have been leached out. Relics of the structural features of the rocks of the basement gneiss complex are in places visible in the saprolite, but to some extent it is, however, strongly sheared sericite- and chlorite-bearing breccia-like schist 
with more or less altered feldspar grains and quartz spots. The saprolite passes over a distance of $10-20 \mathrm{~m}$ towards its base (eastwards) into the rocks of the basement gneiss complex.

The Sariolian basal arkose proper overlies discordantly the saprolitic weathered surface of the basement gneiss complex. It consists of $10-50 \mathrm{~m}$ thick sporadically bedded sericitebearing meta-arkose containing siltstone, calcareous and quartzitic intercalations and pebbles of vein quartz besides sandy layers. The feldspar of the meta-arkose is mainly oligoclase. In places, however, potash feldspar is abundant.

Sariolian basal conglomerate occurs in Pölkkylampi and Viesimo in the commune of Kiihtelysvaara and in Vatala, Tohmajärvi.

In Pölkkylampi a gradual pass from gneissose granite through conglomerate to sericite quartzites can be observed. There is a discordance (Fig. 4) between the basal conglomerate and the gneissose granite. According to Liisa Carlson (1967) a scarcely pebbled paraconglomerate lies undermost in the Pölkkylampi conglomerate, where there are angular pebbles (Fig. 5) markedly varying in size and where sericite-bearing cement abounds. The pebbles derive from the basement gneiss complex and are gneissose granite, tourmaline granite, chlorite schist and hornblende gneiss with additional fragments of quartz and feldspar. The paraconglomerate passes upwards into a homogeneous ortho conglomerate (Fig. 6) where the arkose-like cement is scarcer, the cobbles are big and rounded and the rocks are the same as in the paraconglomerate. - The Pölkkylampi conglomerate contains a bed of breccia-like conglomerate which is a few metres thick and has thin siltstone intercalations (Fig. 7). The cement is arkose-like and the rocks of the cobbles are the same as in the beds described above. - The big-cobbled orthoconglomerate grades over into small-pebbled varieties (Fig. 8). The small rounded pebbles consist of feldspar and quartz grains, quartzite and gneissose granite and some sort of bedding texture is visible. On top of the small-pebbled conglomerate there is

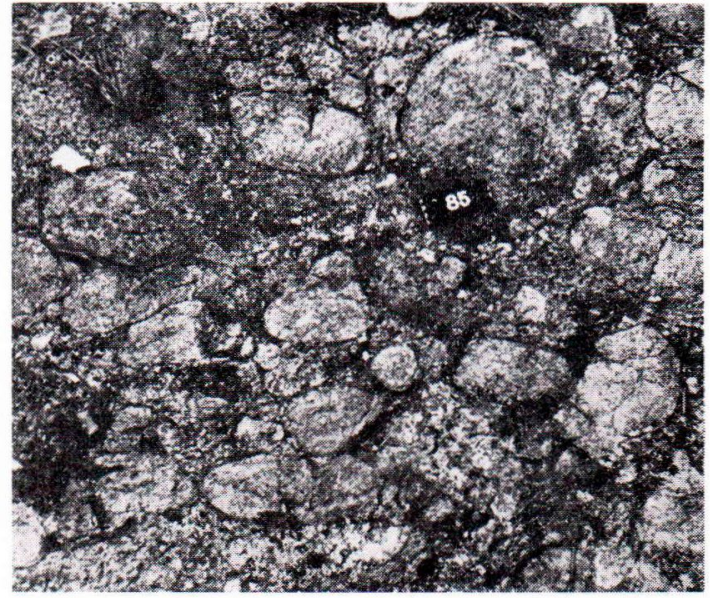

Fig. 6. Conglomerate with largish rounded cobbles from the middle part of the basal conglomerate formation. Kiihtelysvaara, Pölkkylampi. Photo Liisa Carlson.

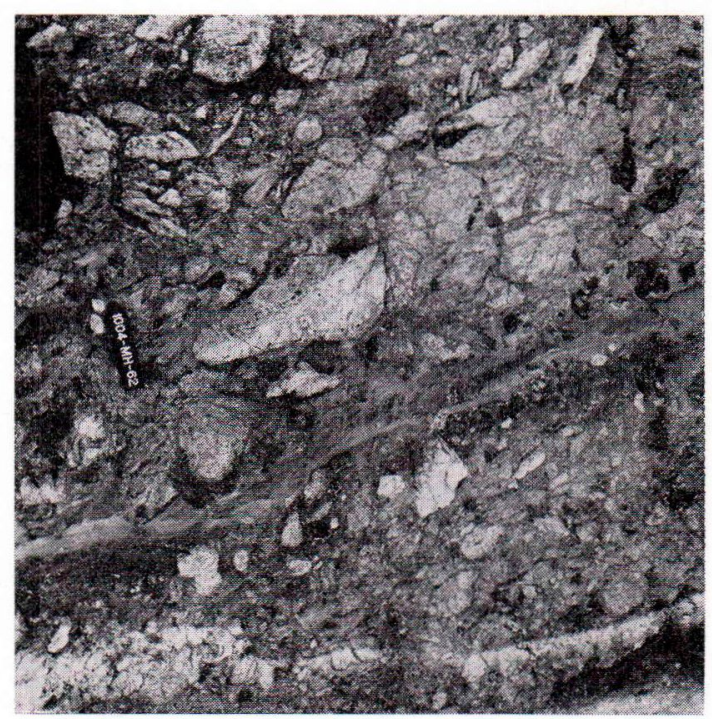

Fig. 7. Siltstone layers in breccia-like conglomerate. Kihtelysvaara, Pölkkylampi. Photo Maunu Härme.

relatively coarse-grained blastoclastic sericite quartzite. The thickness of the Pölkkylampi conglomerate formation from the discordance to the sericite quartzite exceeds 100 metres.

The conglomerate of Viesimo corresponds in structure and composition to the orthoconglom- 
erate. The Vatala conglomerate is a breccialike paraconglomerate.

\section{Kainuan or Jatulian quartzite}

The Sariolian basal beds grade gradually into the Jatulian sericite quartzite or Kainuan

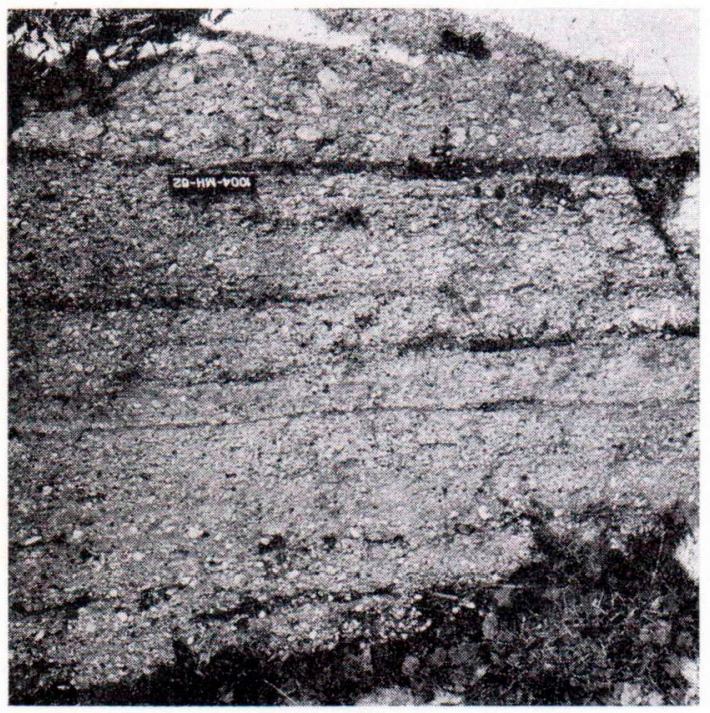

Fig. 8. Small-pebbled arkoses-like conglomerate. Kiihtelysvaara, Pölkkylampi. Photo Maunu Härme.

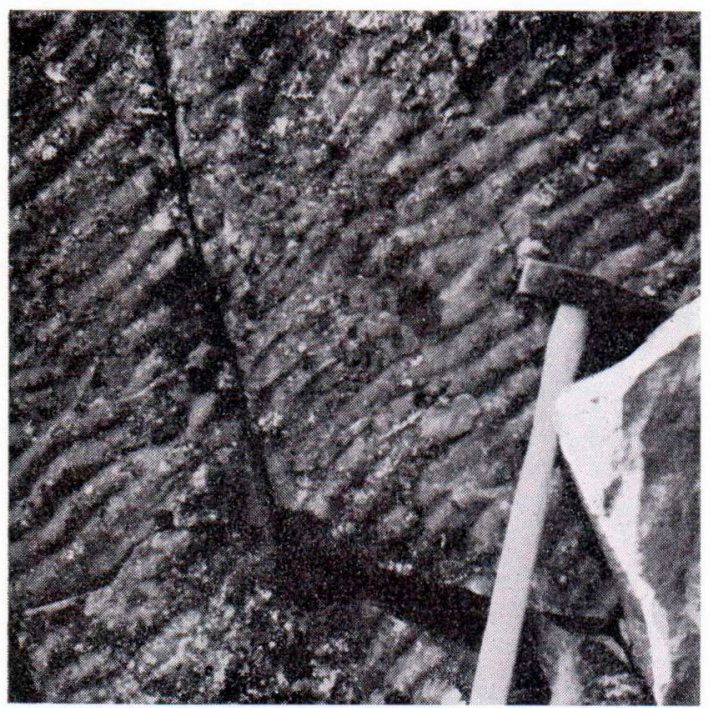

Fig. 9. Ripple marks in Jatulian quartzite. Kiihtelysvaara, Hyypiä. quartzite, which is a stratigraphically most distinctly featured and coherent zone $200-400 \mathrm{~m}$ in thickness. The Kainuan quartzite is pale greenish or yellowish, sometimes bluish, in places even reddish fine or medium-grained, partly coarse blastoclastic rock. Cross bedding is in places visible, likewise ripple marks (Fig. 9). The composition of the Kainuan quartzite is fairly monotonous: besides quartz ( $70-95$ per cent) the sericite varies from 5 to 30 per cent. The sericite quartzite of the lower part of the quartzite formation changes upwards into glassy orthoquartzite. In places - particularly in the lower part of the quartzite - there are beds of arkose quartzite. Here and there the Kainuan quartzite contains quartz conglomerate beds $10-50 \mathrm{~cm}$ in thickness. The quartz pebbles are usually fairly rounded.

\section{Metadiabases, metavolcanics and amphibolites}

Metadiabase was the name given by Väyrynen (1939) to the diabase-like rocks which occur in the Karelides and associate particularly with the Jatulian quartzites. Quite abundant Karelian metadiabase dikes occur in the basement gneiss area (described above on p. 98). The diabase magma intruded during the initial phase of the Karelidic orogeny and occurs in the quartzite zone as basaltic lava and volcanic ejecta. In places in the quartzitic rock, ridge channels may be observed through which the basaltic magma erupted through the quartzite to the surface. In Hyypiä, Kiihtelysvaara, it can be seen how volcanic lava poured into the cracks of the quartzite below. At the contact of the metavolcanics and the quartzite there is a sporadic breccia-like structure where quartzite fragments appear in volcanic lava.

In Hyypiä and Valkiavaara, Kiihtelysvaara, in Vatala, Tohmajärvi and around Värtsilä there are, partly as intercalations in quartzite, basic hypabyssic and metavolcanic beds containing more silicic portions on top of the Jatulian quartzite. The metavolcanic complex 


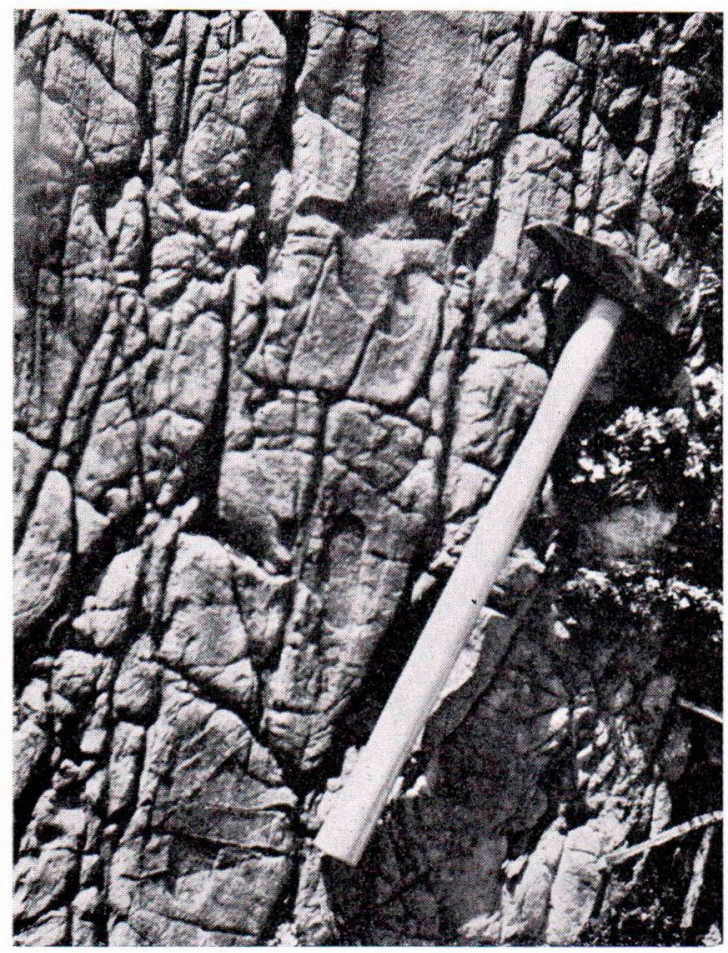

Fig. 10. Cracking of lava in metabasaltic rock. Tohmajärvi, Onkamo.

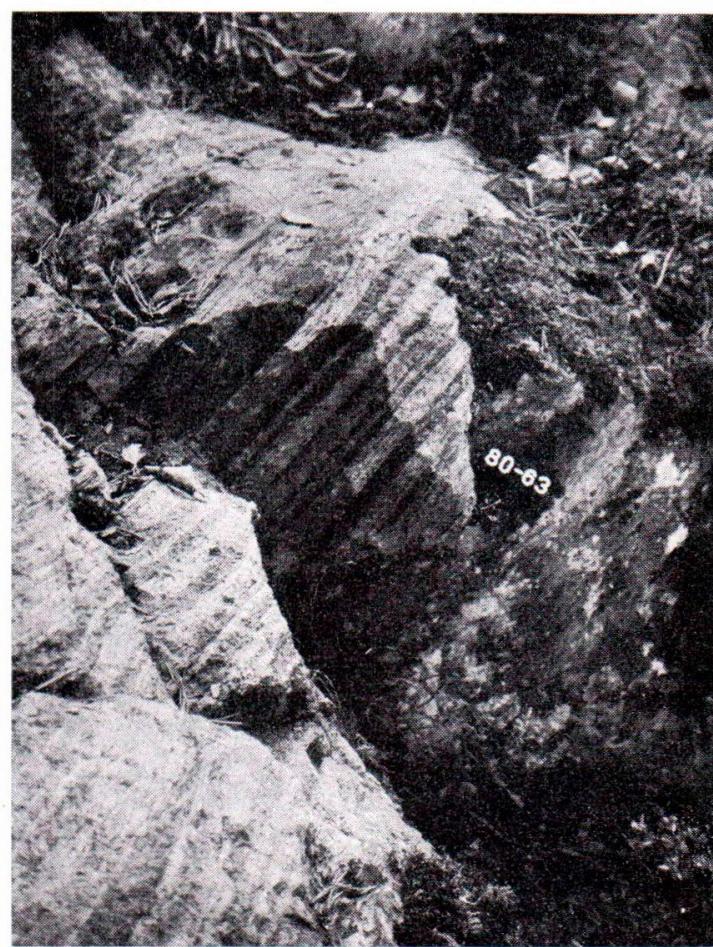

Fig. 11. Stratified tuffite. Tohmajärvi, Kemienmäki, Hirvola. Photo Eero Pokki.

The anticlinal ridge of Tohmajärvi contains an amphibolite-metavolcanic sequence comprising dark green or greenish metaophitic diabases and gabbro-like or porphyritic metabasaltic rocks (Fig. 10). Their mineralogical composition resembles the metadiabase dikes of the basement gneiss area (see p. 98). The amphibole is mainly hornblende, in places it has passed over to tremolite or cummingtonite. The plagioclase is oligoclase. The volcanic complex contains varieties where a breccia-like structure, agglomerate and pillow lava structure are visible. Stratified tuffite intercalations are quite common. In part the tuffites are striped $\mathrm{Na}$-rich silicic or intermediate pyroclastic sediments (Fig. 11), anthophyllite-chlorite albite-quartz-schists in composition mixed with weathering products, and in part they are basic hornblende schists which were mixed with the marine Jatulian black schists in 
the uppermost parts of the metavolcanic complex or which occur as intercalated beds with them.

The metavolcanics and metadiabases contain abundant carbonate, albite and quartz veins. The vein-quartz is most often dark.

\section{Younger or upper quartzites}

In Hyypiä and Raatevaara, the southern part of Kiihtelysvaara, there are so-called younger or upper quartzites intercalated with volcanic beds above the Kainuan quartzite. They differ from the relatively pale and monotonous sericite quartzites in composition and partly also in structure. They are dark in colour, in places quite dark or reddish quartzites. Rather pale sericite quartzites also exist. The dark shades

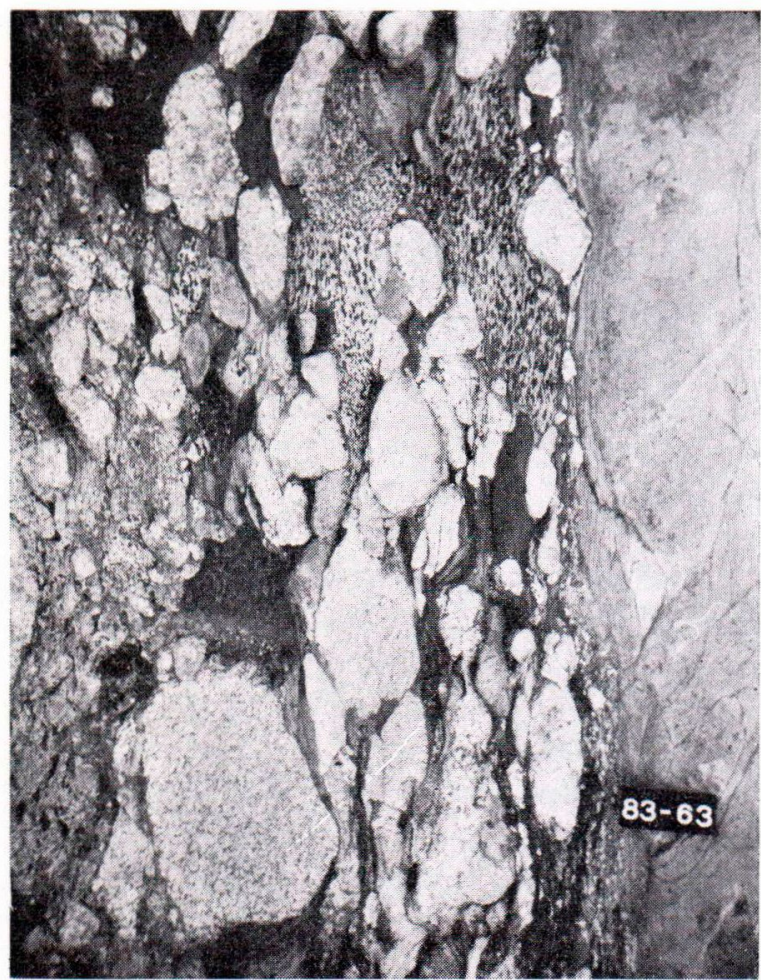

Fig. 12. Conglomerate; cobbles mainly orthogneiss from the basement gneiss area, partly Karelian amphibolite and quartzite. Tohmajärvi, Kirkkoniemi, Photo Eero Pokki. of the younger quartzites derive apparently from the minute spots of iron oxide in the quartz grains (Liisa Carlson 1967). They are blastoclastic in texture. The upper part of the quartzite beds displays brecciated structures caused by the lava which poured upon the quartzite. The metavolcanic matter is in places silicified. Some breccia structures may indicate a weathering breccia. The younger quartzites contain hematite carbonate and arkositic portions as well as some quartz conglomerate beds some tens of metres in thickness.

The anticlinal area of Tohmajärvi contains abundant dark grey, reddish or greyish quartzite beds in connection with the marine Jatulian black schists and dolomites.

The upper quartzites contain $70-95$ per cent quartz, sporadic feldspar and varying amounts of mica, amphibole minerals, tourmaline, sulphides and graphite.

\section{Black schists}

Black schists (carbon phyllites) occur stratigraphically above the metavolcanics. Diamond drillings show that the thickness of the black schist formation varies from 5-50 m. Black schists are either distinctly schistose black or brownish rocks. They associate closely with the marine Jatulian dolomites, dark quartzites and phyllites. The black schists range from fine stratified phyllitic black schists to arenaceous quartzitic black schists or to amphibole-bearing black schists with abundant calcium and magnesium, that is, the so-called Mulo schists. In addition to their high content of graphite, the black schists contain sulphides, amphiboles, micas, quartz, feldspars and carbonate. In Vatala, Tohmajärvi, a graphite layer several metres in thickness associates with black schist. Black schists were originally deposited in a shallow sea as sapropel which possibly contained biogenic constituents. Hyvärinen (discussion 1962) told the author that some small shuttle-like $0.5 \mathrm{~mm}$ long cell structures, beside pyrite stripes may be fossils of the living organisms in the Jatulian Sea. 


\section{Dolomites}

Dolomite overlies the metavolcanics as 5$20 \mathrm{~m}$ thick intercalations with marine Jatulian black schists, phyllites and quartzites. The dolomites are dark grey or rather pale, small- or medium-grained indistinctly stratified rocks. In places, they show miniature folding. They are granoblastic; mosaic-like in texture. The main mineral is dolomite with carbon; additionally mica and clusters of quartz occur. Tremolite skarn portions are frequent. The dolomite zone in Valkiavaara, Kiihtelysvaara, contains a $1-$ $2 \mathrm{~m}$ thick intercalation of hematite.

\section{Intraformational conglomerates and impure arkoses}

An intraformational polymictic conglomerate (about $2 \mathrm{kms}$ long and $0.5-0.7 \mathrm{kms}$ broad) occurs in the anticline of Kirkkoniemi, Tohmajärvi. The dip of the bedding is fairly gentle or $10^{\circ}-45^{\circ} \mathrm{S}$ (Pokki 1965). The cobbles are elongated and only slightly rounded. According to Pokki, the cobbles are generally subangular but in places distinctly angular. The transportation distance of the cobbles may not have been long. The cobbles are mostly $5-25 \mathrm{cms}$ in size, but even boulders $1 \mathrm{~m}$ in diameter have been found. The conglomerate is fairly poorly sorted. Cement is scarce and the cobbles often lie abreast of one another. In the center of the conglomerate occurrence, however, sparsely cobbled and finegrained schist beds are common. In its upper part the conglomerate grades through impure arkose into a staurolite-mica schist. About 7080 per cent of the cobbles are rocks from the basement gneiss area. The rest of the cobbles are Karelidic schists: quartzite, amphibolitic rocks (Fig. 12). The cement of the conglomerate is usually arkose. It contains markedly more quartz than feldspars. Sometimes the cement is carbon phyllite, which may be carbonate- or amphibole-bearing. Narrow quartzite and mica schist intercalations occur. Wilkman (1920) regards the conglomerate of Kirkkoniemi, Tohmajärvi as a Kalevian basal conglomerate.
A many kilometres long zone of coarse impure arkoses with intercalations occurs in the northern part of the anticlinorium from Hammaslahti to Tikkala. The impure arkose is a blastoclastic coarse or medium-grained, in places stratified rock. It contains quartz and plagioclase grains of varying sizes. The cement contains chlorite, mica and sulphides. Sometimes the cement is black schist, sometimes amphibole-rich matter. The impure arkose contains beds of polymictic conglomerate one or two metres in thickness. The rock types of pebbles vary locally to a great extent; they consist of different metavolcanics as tuffites or amphibolites, gneissose granite, phyllite, dolomite, black schist, quartzite, jasperlike quartzite, fragments of feldspar and quartz. The pebbles are mostly longish rounded and partly flattened. The size of a hen's egg is fairly common.

A bed of polymictic conglomerate a few metres thick occurs south of the church village of Kiihtelysvaara between a metavolcanic bed and mica schist. The cobbles of this intraformational conglomerate are mainly of various metavolcanics and quartzite. In the upper part of the conglomerate a thin bed of quartzite occurs immediately below mica schist.

\section{Phyllites and mica schists}

The main part of the Karelidic schists is composed of phyllites and mica schists. They occur in the syncline basins of Höytiäinen and Pyhäselkä and also as intercalations with the marine Jatulian dolomites and black schists. Originally the phyllites and mica schists were chemically rather poorly weathered sediments mixed with sand and clay. These Kalevian flysch sediments are stratified. In places they show distinctly graded bedding or cross bedding. No sharp difference between phyllite and mica schist occurs. Frosterus and Wilkman (1920) pointed out that petrographically the phyllites differ from mica schists in that the structure of the former is finer and the bedding is more easily 


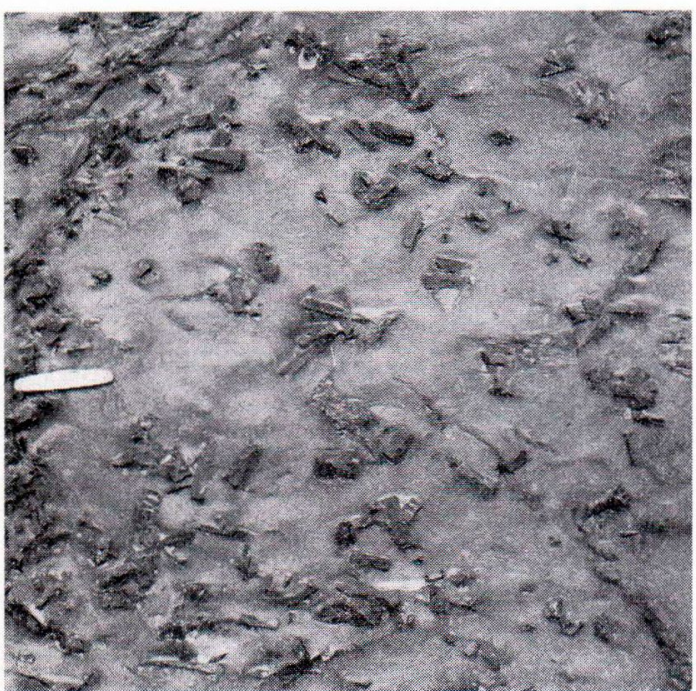

Fig. 13. Staurolite-mica schist. Tohmajärvi, Kemie. Photo Maunu Härme.

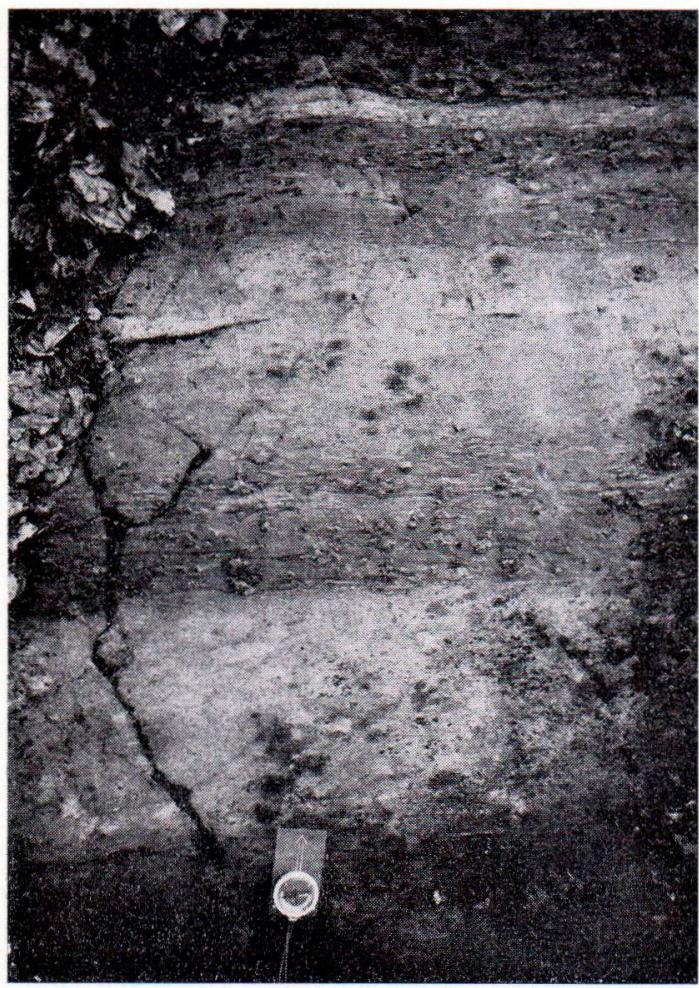

Fig. 14. Graded bedding in porphyroblastic mica schist. Tohmajärvi, Peijonniemi. Photo Eero Pokki. visible. The blastoclastic texture of mica schists and phyllites can be observed under the microscope. It often resembles that of a smallgrained graywacke. Phyllites and mica schists are dark grey rocks where the amount of mica varies from $20-70$ per cent, quartz from $10-60$ per cent and feldspar from $10-50$ per cent. The phyllitic varieties in particular generally contain sulphides and graphite. - As a transitional variety between mica schist and quartzite there is a quartzitic mica schist (Hackman 1933) containing $10-30 \%$ mica, $60-70$ per cent quartz and some feldspar. The thickness of the graded beds of phyllites and mica schists varies considerably: $1-2 \mathrm{cms}$ for a graded bed is common, but in places even greater thicknesses occur. Both phyllites and mica schists include thin $(10-50 \mathrm{~cm})$ intercalations of arkose, quartzite and limestone in abundance.

Concretions are common in the mica schists and phyllites. They are lenticular or ellipsoidal balls containing hornblende, mica, quartz and feldspar, the longest being $30-50 \mathrm{cms}$ in length. In places they are carbonate-bearing.

As a result of metamorphism, porphyroblastic minerals have evolved in the mica schists, namely, staurolite (Fig. 13) andalusite, garnet, cordierite and sillimanite. Staurolite and andalusite crystallized in the bedded mica schists in the finegrained clayey portions of the graded beds (Fig. 14). Staurolite-mica schist occurs both in the anticlinal ridge and at the eastern border of the Karelian schist area. It is evidently located in the lowermost zones of the Kalevian. Fracture cleavage cutting the beds is often visible in the staurolite mica schist and the stress mineral staurolite has often settled accordingly. Andalusite-mica schist appears as a long zone in the syncline basin of Höytiäinen. The andalusite porphyroblasts evidently evolved under relatively slight pressure in the Al-richs sediment. In the mica schist close to the wide granite massif of Kitee, located south of the Tohmajärvi area, sillimanite has crystallized in the contact metamorphism at a relatively high temperature. 
The pegmatite granite of Kitee probably contributed to the development of the porphyroblasts (see Karelidic plutonic rocks). It has spread over a wide area throughout its environment a network of pegmatite and quartz dikes. In connection with contemporaneous movements is has caused a metamorphism which has led to the crystallization of porphyroblastic minerals in the phyllites and mica schists. Recrystallization probably occurred under conditions of amphibolite facies (staurolite subfacies and andalusite subfacies). The andalusite subfacies represents a higher temperature than the staurolite subfacies, the mineral assemblages of which originated under higher pressure as a result of stronger movements. The occurrence of sillimanite indicates a high crystallization temperature.

\section{Karelidic plutonic rocks}

There are small pegmatite granite intrusions in the Karelidic schist belt in the southern part of the Tohmajärvi area. The pegmatite granite belongs to the so-called Kitee granite, which forms a massif measuring over 200 square kilometers south of the map area. The Kitee granite penetrates the Karelidic schists and belongs to the late-kinematic Karelidic plutonic rocks. The minerals of the coarse-grained rather pale Kitee granite are potash feldspar, oligoclase, quartz, muscovite, tourmaline, garnet, apatite, biotite and graphic feldspar.

In the center of the andalusite mica schist area of Petravaara, Tohmajärvi, there is an occurrence of grey mediumgrained trondhjemitic rock a few square kilometres in breadth. Its principal minerals are plagioclase $\left(A n_{15-25}\right)$, quartz and biotite of which there are $40-70 \%, 20-40 \%$ and $10-20 \%$ respectively. The Petravaara trondhjemite likewise belongs to the orogenic plutonic rocks which penetrate the Karelidic schists.

\section{Structure}

The tectonics of the Tohmajärvi area is dominated by the general trend of the Karelidic schist belt, i.e. about NNW. This line is also followed by the contact of the basement gneiss complex and the Karelidic schists. Also the basement gneiss complex, the general orientation of the gneiss is by and large the same as in the Karelidic schist belt. The Karelidic schists of Tohmajärvi are situated in a wide axial depression where the fold axis plunges gently or more steeply toward Lake Ladoga (Wegmann 1928). Besides the larger folds which show up on the geological map, abundant smaller folds are to be found in the field. Minor folds are visible. Particularly in the phyllites and mica schists, in places also in the dolomites and amphibolites. The fold axes and the elongations of minerals and conglomerate cobbles are parallel to the direction of the tectonic b-axis. The axial planes of the folds slope more or less steeply westward.

The bedding and schistosity are generally parallel. However, particularly in the anticline area the conglomerates, quartzites, amphibolites and typically the staurolite-mica schist show transversal schistosity. In the syncline area as well as close to the contact of the basement gneiss complex the dip of the schistosity and the stratification is mostly steep or vertical. On the contrary, in the anticline area gentle dips are abundant alongside the steep ones. In the basement gneiss complex steep and verticál dips are predominant.

The cataclastic structure of the basement gneiss complex may derive from the Karelidic movements. The basement gneiss seems to have broken into blocks during the movements which are manifested as the long rupture valleys of the area. Quite abundant metadiabase intrusions have intruded into these fracture and shear zones. The folds met with here and there in the basement gneiss area are probably pre-Karelian in age. 


\section{Stratigraphy and sedimentation}

The rocks of the pebbles of the Sariolian basal conglomerates show that their material and that of the basal arkose derive from the basement gneiss complex. The basal arkose originated during the weathering of the basement gneiss complex and deposited gradually on the levelled paneplain. The conglomerates deposited in the valleys are relics of the greater differencies in altitude. R. W. Ojakangas (1965) pointed out a fluvial deposition of the conglomerates in Pölkkylampi and Viesimo.

The deposition of quartz sands upon the Jatulian continent, which was eroded to a peneplain, associated with the transgressive spreading of a shallow sea upon dry land. The ripple marks and cross bedding structures met with in quartzites refer to coastal formations. Due to the slight differences in topography the coarser quartz matter did not deposit as very thick occurrences and thus e.g. the quartz conglomerate beds are just a few tens of centimetres thick.

During the marine transgression in the Jatulian era conditions became gradually less peaceful taking on the form of volcanic activity. Basaltic lava flowed upon quartz sands or quartz sandstone as is shown by the lava runs in the quartzites and by the mixed structures of volcanics and quartzites. The magma had at least to some extent differentiated when it erupted to the surface. Already in the steeply located Karelian metadiabase dikes met with in the basement gneiss area a slight differentiation is observable in that the border zones are of basic rock and that in the center of the dike there is a narrow quartz-rich leucodiabase zone. It is possible that similar differentiation occurred gravitatively before the lava and ash eruptions in which case the matter of the relatively narrow silicic or intermediate $\mathrm{Na}$-rich material appears in some tuffite beds and albite-rich amygdaloidal rocks.

As soon as the volcanic activity began, the deposition of the quartz sands continued in the somewhat altered conditions. Increasing topo- graphical differences in altitude are manifested by relatively thick quartz conglomerate beds. The matter of the upper or dark quartzites may at least partly derive from the weathered volcanics. The metavolcanics of the area contain abundant dark shaded quartz dikes. In other places - e.g. in Kemie, Tohmajärvi - the gradual alteration of tuffites into black schists indicates that the volcanic ashes deposited into a shallow sea and partly mixed with sapropel and calcareous sediments.

With the increasing transgression these shallow sea sediments - sapropel and dolomitic limestones - deposited either upon the quartz sands or directly upon the pre-Karelian basement gneiss. The volcanic activity which preceded or occurred simultaneously with the deposition of sapropel and dolomites produced among others nitrogen, carbon dioxide, methane, hydrogen sulphide and water and thus improved the conditions for primitive organic activity. Väyrynen (1954) assumes that primitive algaelike organisms used to live in the Jatulian sea. The fore mentioned (p. 102) cell-like structures found in black schists by Hyvärinen sustain the hypothesis of Väyrynen.

The precipitation of carbonates in the Jatulian sea evidently took place at least partly through the action of organisms. It is far from certain whether they precipitated as magnesium carbonates or originated as calcium carbonates dolomitized by $\mathrm{Mg}$-bearing solutions. The change from dolomite into calcite rock may have been caused by the earlier change of facies (Väyrynen 1954).

According to Väyrynen (1954), the transgression of the Jatulian sea was caused by the epeirogenetic movements, in other words by the return of the isostatic balance. The levelling of the Jatulian continent to a peneplain caused sedimentary material to be transported to the border parts of the continent which gradually sank and thus caused the rise of the water level.

When the movements became orogenic coarse poorly weathered residual sediments: conglomer- 
ates and impure arkoses deposited on the slopes of the rising anticlinal ridges into the synclinal basins which formed during the orogeny. Chemically relatively poorly weathered sediments mixed with sand and clay: the present stratified phyllites and mica schists deposited. In places it is possible in the fleld to observe a gradual transition from a conglomerate through a coarse arkose into a finer graywacke-like mica schist and phyllite.
During the late phases of the orogenic movements granitic plutonic rocks intruded and they caused regional metamorphism and recrystallization under the conditions of the amphibolite facies, whereas among others porphyroblastic minerals as staurolite and andalusite originated.

The stratigraphy of the Karelian formation in the Tohmajärvi area is schematically illustrated as follows:

Uppermost

Phyllites and mica schists

Impure arkoses and intraformational conglomerates

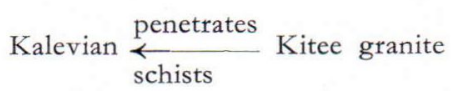

Phyllites, black schists, dolomites and quartzites

Quartzites as alternating layers with metavolcanics, quartz conglomerate intercalations

Sericite quartzite where the upper part is orthoquartzite

Basal conglomerate and basal arkose

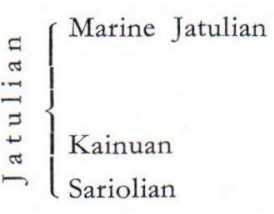

Great discordance

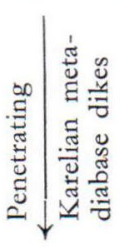

Pre-Karelian basement gneiss complex

\section{Lowermost}

Acknowledgment - The Head of the Petrological Department Prof. Ahti Simonen and the State Geologist Dr. Maunu Härme, showed keen interest in this work and their fruitful criticism is greatly appreciated. Mrs. Lea Torssonen redrew the pictures, Mrs. Toini Mikkola, Lic.
Phil., translated the text into English and Mrs. G. Häkli corrected and revised the language. To them and to all persons who assisted me in one way or an other I want to express my sincere gratitude.

\section{REFERENCES}

Carlson, Lirsa (1967) Jatulimuodostumien ja niihin liittyvien metavulkaniittien stratigrafiasta Kiihtelysvaaran pitäjän lounaisosissa. Manuscript at the Geol. Min. Inst., Univ. Helsinki.

Eskola, Pentti (1925) On the petrology of Eastern Fennoscandia. 1. The mineral development of basic rocks in the Karelian formations. Fennia 45, No 19.

- (1963) The Precambrian of Finland. pp. 145-279 in Precambrian I; edited by Kalervo Rankama. Interscience Ltd.
Frosterus, BenJ. (1902) Bergbyggnaden i sydöstra Finland. Referat: Der Gesteinsaufbau des südöstlichen Finland. Bull. Comm. géol. Finlande 13.

Frosterus, Benj. ja Wilkman, W. W. (1920) Vuorilajikartan selitys D 3, Joensuu. Explanation to the general geological map of Finland. 1: 400000.

Hackman, V. (1933) Kivilajikartan selitys D 2, Savonlinna. Explanation to the general geological map of Finland, $1: 400000$. 
HYvärinen, LAUri (1962) Oral communication on Karelian fossils.

Kouvo, Olavi (1958) Radioactive age of some Finnish pre-Cambrian minerals. Bull. Comm. géol. Finlande 182.

- and Tilton, G. R. (1966) Mineral ages from the Finnish Precambrian. Journal of Geology, Vol. 74, pp. $421-442$.

Miknola, Torvo (1953) Peruskalliogeologian näköaloja. Geologi 5, p. 29.

- (1961) Sediment groups, particularly flysch, of the Precambrian in Finland. Compt. Read. Soc. géol. Finlande 33, Bull. Comm. géol. Finlande 196, pp. $51-63$.

NYKänen, Osmo (1968) Kallioperäkartan selitys. LehtiSheet 4232 - 4234, Tohmajärvi. Explanation to the map of rocks. Geological Map of Finland 1 : 100000.

Ojakangas, Richard W. (1965) Petrography and sedimentation of the Precambrian Jatulian quartzites of Finland. Bull. Comm. géol. Finlande 214.

Pokkr, Eero (1965) Havaintoja Tohmajärven konglomeraatista ja sitä ympäröivistä kivilajeista. Manuscript at the Geol. Min. Inst. Univ. Helsinki.

Ramsay, W. (1902) Om de prekabriska formationerna och bergveckningarna i den sydöstra delen af Fennoskandia. Geol. Fören. i Stockholm Förh. Bd. 24, p. 28.

Sederholm, J. J. (1893) Om bärggrunden i Södra Finland. Fennia 8, No 3.

- (1897) Om indelning af de prekambriska formationerna i Sverige och Finland och om nomenklaturen för dessa äldsta bildningar. Geol. Fören. i Stockholm Förh. Bd. 19, p. 20.

Simonen, Ahtr (1953) Stratigraphy and sedimentation of the Svecofennidic, early Archean supracrustal rocks in south-western Finland. Bull. Comm. géol. Finlande 160 .
- (1960) Precambrian stratigraphy of Finland. Int. Geol. Congress. XXI Session, Norden, pt. IX, pp. 141-153.

- (1960) Pre-Quaternary rocks in Finland. Bull. Comm. géol. Finlande 191.

Tigerstedt, A. F. (1892) Om traktens mellan Höytiäinen och Pielisjärvi geologiska och topografiska byggnad, samt några därstädes förekommande malmförande kvartsgångar. Referat: Zur Geologie und Topographie der Gegend zwischen den Seen Höytiäinen und Pielisjärvi im nordöstlichen Karelien. Fennia 5, No. 10.

Wegmann, C. E. (1928) Über die Tektonik der jüngeren Faltung in Ostfinnland. Fennia 50, No. 16.

- (1929) Über alpine Tektonik und ihre Anwendung auf das Grundgebirge Finnlands. Compt. Rend. Soc. géol. Finlande 1. Bull. Comm. géol. Finlande 85, pp. $49-53$.

Wetherill, G. W., Kouvo, O., Tilton, G. R. and Gast, P. W. (1962) Age measurements on rocks from the Finnish Precambrian. Journal of Geology, Vol. 70, pp. $74-88$.

WIIK, F. J. (1874) Om östra Finlands primitiva formationer. Bidr. till Finlands natur och folk 21, Helsingfors.

Wilkman, W. W. (1932) Tohmajärvi-konglomerat och dess förhållande till kaleviska skifferformationen. Bull. Comm. géol. Finlande 62.

VäYrYNeN, HeIKki (1933) Über die Stratigraphie der Karelischen Formationen. Bull. Comm. géol. Finlande 101 , pp. 54-78.

- (1939) On the geology and tectonics of the Outokumpu ore field and region. Bull. Comm. géol. Finlande 124, pp. 1-91.

- (1954) Suomen kallioperä. Tiedekirjasto No 27, Otava.

Manuscript received, May 23, 1970. 